DOI https://doi.org/10.36059/978-966-397-199-5/22-42

\title{
"THE SWEET AND WITTY SOUL OF OVID LIVES IN MELLIFLUOUS AND HONEY-TONGUED SHAKESPEARE": INTERPRETATION OF THE ANCIENT PLOT IN SHAKESPEARE'S VENUS AND ADONIS
}

\section{Hanna M. Blondel (Khrabrova)}

\section{INTRODUCTION}

The myth of Venus and Adonis achieved tremendous popularity in the Age of the Renaissance. It inspired the great artists, in particular Titian ("Venus and Adonis", 1554), Paolo Veronese ("Venus and Adonis", 1580 ) and Annibale Carracci ("Venus, Adonis and Cupid", 1595), whose masterpieces make part now of the collection of Madrid's Museo del Prado.

The story about the goddess's affection for a young mortal, who prefers hunting to love, was very influential in the Elizabethan Age. The Elizabethan men of letters aspired to compose their poetic treatments of the ancient myth in an original and exceptionally ingenious manner. For example, in Spenser's The Faerie Queen (first published in 1590), the tale of Venus and Adonis was represented on an extraordinary tapestry in the Castle Joyous (Book III). In Marlow's Hero and Leander (first published in 1598) it appeared as embroidered on the sleeve of Hero's gown.

At last, the story of Venus and Adonis constituted the background for Shakespeare's erotic narrative poem, which made a great contribution to the development of erotic poetry writing of the period.

The poem Venus and Adonis (1593) holds a special place in the Shakespeare canon. In his dedication to Henry Wriothesley, Earl of Southampton, the author calls it "the first heire of my inuention". At first glance, these Shakespeare's words might seem a little strange, as The Henry VI trilogy (1590-1592) had been written since before the narrative poems. However, it becomes clear when one remembers that the 'fine art connoisseurs' of those times recognized as true only 'pure' poetry, which was regarded as the guarantor of a solid literary reputation, while theatrical plays were treated as a low métier intended for the common people ${ }^{1}$.

\footnotetext{
${ }^{1}$ Морозов М. М. Встреча с графом Саутгэмптоном. “Венера и Адонис".
} “Лукреция”. Шекспир. Москва, 1956. С. 25. 
In addition, it should be noted that this poem was the first printed work by Shakespeare, and due to it he owed both an amazing rise in popularity (it was reprinted 10 times during 10 years, between 1593 and $1613^{2}$ ) and a significant improvement in his financial situation (a generous reward of the Earl of Southampton who was a noble patron of the arts, laid a solid foundation for the future playwright's well-being).

\section{Literary critical reception of the Bard's poem}

A remarkable success of Shakespeare's poem was evidenced by his contemporaries' literary appraisals. Some of them testified that it was phenomenally successful among young people. The Elizabethan man of letters Gabriel Harvey, for example, wrote that "the younger sort take much pleasure in Shakespeare's Venus and Adonis..."”. There were also echoes of its amazing popularity in the second Parnassus Play of the trilogy, staged by the students at St. John's College, Cambridge, in 15981601. The character Gullio declared his love for "sweet Master Shakespeare" and announced: "Let this duncified world esteem of Spenser and Chaucer, I'll worship sweet Mr. Shakespeare, and to honour him will lay his Venus and Adonis under my pillow".

It was thanks to Venus and Adonis, as well as his other poem The Rape of Lucrece, that W. Shakespeare got a coveted title of 'the Ovid of England'. The Elizabethan critic Francis Meres praised Shakespeare's poetry in Palladis Tamia, Wits Treasury (1598): "As the soul of Euphorbus was thought to live in Pythagoras, so the sweet witty soul of Ovid lives in mellifluous and honey-tongued Shakespeare, witness his Venus and Adonis, his Lucrece, his sugared Sonnets among his private friends" $" 5$.

Richard Barnfield in his collection Poems in Diverse Humours (1598) published a poem headed A Remembrance of Some English Poets, where he also addressed his lines to Shakespeare in a high strain of panegyric, referring specifically to his poetry:

And Shakespeare thou, whose honey-flowing Vein

(Pleasing the World), thy Praises doth obtain. 2004. P. 245.

${ }^{2}$ Greenblatt S. Will in the World. How Shakespeare became Shakespeare. London,

${ }^{3}$ The New Oxford Shakespeare: The Complete Works / ed. by G. Taylor, J. Jowett, T. Bourus, G. Egan. Oxford, 2016. P. 639.

${ }^{4}$ Wells S. Shakespeare For All Time. London, 2002. P. 68-69.

${ }^{5}$ Ibid. P. 54. 
Whose Venus, and whose Lucrece (sweet and chaste)

Thy Name in fame's immortal Book have placed.

Live ever you, at least in Fame live ever:

Well may the Body die, but Fame dies never ${ }^{6}$.

John Weever's epigram Ad Gulielmum Shakespeare (1599) dedicated to the "honey-tongued" poet, declared that "Rose-cheek'd Adonis with his amber tresses", "Faire fire-hot Venus charming him to love her" and his other characters seem the creations of the god Apollo "and none other",

However, even during the life of the author, the reception of Venus and Adonis was rather ambiguous. Some Renaissance masters of the word considered the poem as a herald of fornication. Thus, in one of the epigrams written in 1614, Thomas Freeman stated:

Who list read lust, there's Venus and Adonis,

True model of a most lascivious lecher ${ }^{8}$.

A similar opinion was expressed by the poet John Davies (1569? 1626) in the work "A scourge for paper-persecutors. Or Papers Complaint, compil'd in ruthfull Rimes Against the Paper-spoylers of these Times", complaining that the "immortal poems" serve as a powerful propaganda of lust in the image of Venus, who compels Adonis to satisfy her love passion:

Another (ah Lord helpe) mee vilifies

With Art of Loue, and how to subtilize,

Making lewd Venus, with eternall Lines,

To tye Adonis to her loues designes $:^{9}$

Further, Davies explained that the poems contained an exquisite wit, but it would have been more refined not to put on lustful attire:

Fine wit is shew'n therein: but finer twere

If not attired in such bawdy Geare ${ }^{10}$.

Some centuries later, the famous English critic William Hazlitt (1778-1830), regarding Shakespeare's poems as "cold and glittering", compared them to "ice houses"11.

${ }^{6}$ Gililov I. The Shakespeare Game, Or, The Mystery of the Great Phoenix. New York, 2003. P. 126.

${ }^{7}$ Srinivasa Iyengar K. R. Shakespeare: His World and His Art. Delhi, 1984. P. 293.

${ }^{8}$ Wells S. Shakespeare. A life in Drama. New York - London, 1997. P. 120.

${ }^{9}$ Srinivasa Iyengar K. R. Shakespeare: His World and His Art. P. 294.

${ }^{10}$ Ibid. 
In modern times the Great Bard's poems have been on the margins of research attention, significantly inferior to dramaturgy and sonnets both in the number of publications devoted to them and in the intensity of the scholars' appeals. The whole set of works, focused on Shakespeare's Venus and Adonis, can be divided, with a certain degree of convention, into two main categories: representative-review papers and proper analytical ones.

The first category is mostly represented by the prefaces to numerous editions of the poem and contains, as a rule, a summary list of Shakespeare's contemporaries' reviews of his work, a brief excursion into the history of the functioning of the mythological plot that inspired 'the Bard of Avon', as well as plot retelling supplemented by comments. The value of such research papers is that they "fit" Shakespeare's text into the general literary panorama of the era and highlight the nature of the interaction between tradition and innovation.

For example, Vasily Botkin, the Russian Shakespearean scholar of the $19^{\text {th }}$ century, pointed to the Bard's use of a new approach to the representation of love in comparison with his predecessors: "Love depicted before him by English and Italian authors in their mythological poetry was nothing more than an artificial intricacy of thoughts of love, framed in sophisticated forms, which were more polished by phrases than by the intrinsic truth of feeling. In Shakespeare's poem, on the contrary, love is 'a spirit all compact of fire', madness and passion - and this concept of love flows through all the manner of representation"12.

Noteworthy is V. Botkin's comparison of Venus and Adonis with paintings. The researcher reveals that this poem "is reminiscent of mythological pictures of the Flemish, depicting ... a goddess of beauty with excessively magnificent and delusional forms. This naive and sweet anachronism is reflected in all the arts of the time, including the most ingenious Italian paintings" $"$.

It should be noted that the scholars quite often resort to comparing Venus and Adonis with paintings. For example, Mikhail Morozov, the

11 A Companion to Shakespeare Studies / ed. by H. Granville-Barker, G. B. Harrison. New York, 1960. P. 104.

12 Боткин В. П. Литература и театр в Англии до Шекспира. Полное собрание сочинений В. Шекспира в переводе русских писателей: в $3 \mathrm{~m}$. / под ред. Д. Михаловского. Санкт Петербург, 1899. Т. 3. С. 5-41. URL : http://az.lib.ru/b/botkin_w_p/text_ 0110oldorfo.shtml.

13 Ibid. 
Soviet literary and art critic who devoted himself to the study of Shakespeare, pronounces that "Shakespeare wanted to write a work worthy of the sophistication of Sydney and Spencer. However he could create with his brush much more saturated colors. Reading some fragments of the poem gives the impression that it was the full-blooded Flemish who made a copy from a light Italian painting" $"$.

The important Soviet Shakespearean scholar, Aleksandr Anikst expresses the thought sounding in unison: "Due to Shakespeare's pen, the ancient myth acquires a sensual completeness and picturesqueness making us recall the Italian Renaissance painters' masterpieces ... A pastoral landscape with green fields and dense forests emerges before the reader. There are birds singing in the trees and beasts penetrating through the thickets. All nature is spiritualized, and we see two gorgeous creatures within it. They are endowed with all the features of bodily beauty" ${ }^{\prime \prime}$.

The Ukrainian researcher Olena Alekseenko, in her afterward to Venus and Adonis, contained in the six-volume edition of the complete works of Shakespeare in Ukrainian (1984-1986), draws parallels between Shakespeare's poetic debut and the love poetry of the other Renaissance men of letters (Francesco Petrarca, Giovanni Boccaccio, Torquato Tasso, Thomas Campion, George Gascoigne, Edmund Spenser), and she also highlights that "the poem Venus and Adonis is constructed in the same way the Renaissance paintings were made ... It is pierced with bright light and opened to the outside"

On O. Alekseenko's opinion it is interesting to emphasize the irony of the author's attitude to Adonis and the fact that the death of the character is a natural consequence of his violation of the law of nature: "Disharmony is becoming worldwide. The embodiment of the destructive forces of nature is death. However, it is not the Fatum of ancient tragedies that haunts the heroes. The very death that comes in the form of a wild boar is natural here. This is the part of nature that has lost its harmony"17.

14 Морозов М. М. Встреча с графом Саутгэмптоном. "Венера и Адонис". “Лукреция”. С. 22.

15 Аникст А. А. Поэмы, сонеты и стихотворения Шекспира. У. Шекспир. Полное собрание сочинение: в 8 m. / под ред. А. Смирнова, А. Аникста. Москва, 1960. T. 8. C. 570.

${ }^{16}$ Алексєєнко О. Венера і Адоніс / пер. 3 англ. О. Мокровольського. Шекспір В. Твори : в 6 m. Київ, 1986. Т. 6. С. 770.

${ }^{17}$ Ibid. C. 771. 
The Russian Shakespearean scholar Valentina Komarova tells about the allegorical interpretation of beauty, embodied by a young hunter: "The death of Adonis is one of beauty, without which the world loses its most important treasure" ${ }^{\text {. }}$.

The original observations on the style of Shakespeare's poem are contained in the preface included in the so-called Bevington edition of The Complete Works of Shakespeare (1997). A prominent American scholar of Shakespeare, David Bevington convincingly argues that Venus and Adonis being mouthpieces for contrasting attitudes toward love, "debate a favorite courtly topic in the style of John Lyly. Both appeal to conventional wisdom and speak in sententiae, or aphoristic pronouncements ... In substance, their arguments are equally conventional ... The debate is, in a sense, an ingeniously elaborate literary exercise, yet it also allows for reflection on contrasting views of love as sensual and spiritual, absurd and magnificent, funny and serious" 19 .

We can't but agree with D. Bevington's statements concerning the narrator's ambivalent attitude to the debate and the role of irony in the poem's artistic space, which is "also suffused with the rich pathos of sensuous emotion ... The sensuousness would cloy without the ironic humor, whereas the humor would seem frivolous without the pathos" 20 . His reflections on the significance of allegory in the poem are also beyond doubt: an allegorical interpretation of the image of Venus who "represents herself as the goddess not only of erotic passion, but also of eternal love conquering time and death ..., elevates the seriousness, adding poetic dignity to what might otherwise appear to be an unabashedly erotic poem $^{21 "}$. All this justifies the conclusion that "we should not minimize the sexual teasing or fail to acknowledge our own erotic pleasure in it" ${ }^{\prime 22}$.

In the context of this research paper, it is appropriate to cite the opinion of Michael Dobson, the Director of the Shakespeare Institute in Stratford-upon-Avon and Professor of Shakespeare Studies at the University of Birmingham (since 2011), who sets down the uniqueness of

18 Комарова В. П. Чувственность и разум в поэмах "Венера и Адонис" и “Обесчещенная Лукреция". Метафоры и аллегории в произведениях Шекспира. Ленинград, 1989. С. 28.

${ }_{19}$ Bevington D. Venus and Adonis. The Complete works of Shakespeare / ed. by D. Bevington. New York, 1997. P. 1608-1609.

${ }^{20}$ Ibid. P. 1609.

${ }^{21}$ Ibid. P. 1608.

${ }^{22}$ Ibid. 
this poem to the unusual distribution of gender roles. According to his observation, "it remains one of the few major works in world literature to depict the passionate pursuit of a male object by a female subject"23.

The second category of research works includes the articles highlighting a specific issue related to the poetics of Shakespeare's "Venus and Adonis", as well as the papers in which analytical observations on the poem are interwoven into a wider research space. For example the works of T.W. Baldwin and Geoffrey Bullough gather together all those texts that could have served original sources for Shakespeare's writing.

G. Bullough in his anthology of prose and verse Narrative and Dramatic Sources of Shakespeare, traces the genetic connection of Shakespeare's poem not only with the classic version of the myth of Venus and Adonis by Ovid, but also with the other stories recounted by the Roman poet in The Metamorphoses. The scholar proves that in addition to the well-known tenth book, including the tale of Venus's love for Adonis, Shakespeare also used two other plots from Ovid's magnum opus, namely the story of Salmacis and Hermaphrodites (Book IV), and one of Narcissus and Echo (Book III) ${ }^{24}$.

So, such narrative threads as Venus's amorous eagerness and sexual initiatives, the descriptions of Adonis's appearance, who flushes with embarrassment caused by the obscene suggestions of the goddess of love (lines 49-50; 76-78), the disputes about kisses (lines 84-89; 115-128) and hugs (lines 52-72; 225-30), as well as the handsome hunter's resistance (lines $379 ; 710$ ), are influenced by the fourth book of the Latin narrative poem (IV. 285-388) ${ }^{25}$.

From the story of Narcissus and the nymph Echo (III. 341-510) Shakespeare borrows the accusations of self-admiration that Venus uses as an argument, aspiring to lure Adonis" ${ }^{, 26}$.

T. W Baldwin reveals the ideological connection between Shakespeare's poem and the works by Erasmus of Rotterdam. The scholar

${ }^{23}$ Dobson M. Venus and Adonis. The Oxford Companion to Shakespeare / ed. by M. Dobson, S. Wells. Oxford, 2008. P. 510.

${ }^{24}$ Bullough G. Narrative and Dramatic Sources of Shakespeare. London, 1975. P. 161-165.

${ }^{25}$ Ibid.

${ }^{26}$ Ibid. 
remarks that the very idea of discussing different views on procreation became popular in England thanks to the author of The Enchiridion ${ }^{27}$.

Iurii Shvedov, one of the leading representatives of the Soviet studies of Shakespeare, analyzes Venus and Adonis in the context of all Shakespeare's work. The scholar attributes the basis of the conflict in the poem to "the clash of two ethical principles represented by Venus and Adonis. The goddess is a passionate defender of free love.., an adherent of the Renaissance moral values, who opposes the medieval asceticism to the pursuit of happiness not in the otherworld, but here on the Earth... Adonis avoiding Venus's caresses acts as a carrier of opposite moral principles ${ }^{28, "}$.

Rather original observations on the poetics and semantics of Shakespeare's poem belong to the Russian poet and translator Grigori Kruzhkov. While working on the translation of Venus and Adonis, he carefully reconstructed the sociocultural context of the poem, its edition history, its connections with the mythological source, as well as with ethical, philosophical and aesthetic theories of the epoch.

Emphasizing on Shakespeare's unique ability to create the impression of harmony in the distribution of dark and light spots, G. Kruzhkov draws a number of parallels with the picturesque and stylistic techniques. He writes: "Shakespeare's poem moves from love to death with the inevitable logic of a Spanish romance or a Scottish ballad. How is it possible to believe that Adonis who offends the Goddess of Love could get away with it! ${ }^{29,}$.

Quite unusual and convincing at the same time is G. Kruzhkov's assumption about the correlation of Venus and Adonis with politics. He identifies several levels of such correlation. First, "any love poem, whose protagonist was a goddess or princess, certainly acquired a political aspect in the Elizabethan period ... Not only politics were eroticized, but love poetry was also largely politicized: the anxieties and sorrows of love were often expressed in the terms of court service ${ }^{30,}$.

${ }^{27}$ Baldwin Th. W. On the Literary Genetics of Shakespeare's Poems and Sonnets. Urbana, 1950. P. 183-186.

28 Шведов Ю. Ф. Творчество Шекспира. Вильям Шекспир. Исследования. Москва, 1977. С. 278.

${ }^{29}$ Кружков Г. М. Лекарство от Фортуны. Поэты при дворе Генриха VIII, Елизаветы Английской и короля Иакова. Москва, 2002. С. 191.

${ }^{30}$ Ibid. C. 199. 
Secondly, Elizabeth I herself was regularly associated with Venus, and her love for hunting enables to find out in Shakespeare's descriptions of the skills of Venus that the author compared to Diana an allusion to the Queen of England ${ }^{31}$. The Elizabethan literary critic George Puttenham, in his address to the queen, said "she was Venus in countenance, in life Diana...", and this metaphorical image of Elizabeth I, on G. Kruzhkov's opinion, could hypothetically be referred to Shakespeare's popular poem of that time ${ }^{32}$.

James H. Lake in his polemic article Shakespeare's Venus: An Experiment in Tragedy, notes that the scholarly reception of the poem has been rather ambivalent. Some researchers, particularly, C. S. Lewis (English Literature in the Sixteenth Century: Excluding Drama), R. Putney (Venus Agonistes), B. E. Cantelupe (An Iconographical Interpretation of "Venus and Adonis", Shakespeare's Ovidian Comedy), M. C. Bradbrook (Beasts and Gods: Greene's Groats-Worth of Witte and the Social Purpose of "Venus and Adonis") consider Shakespeare's Venus and Adonis as a tedious failure poem aimed at satisfying the tastes of the Earl of Southampton ${ }^{33}$.

The other scholars, as H. T. Price (The Function of Imagery in "Venus and Adonis), R. P. Miller (Venus, Adonis, and the Horses), A. Ch. Hamilton (Venus and Adonis), J. W. Lever (Venus and the Second Chance), K. A. Muir ("Venus and Adonis": Comedy or Tragedy?), N. Rabkin (Shakespeare and the Common Understanding) generally share the ideas of one of the pioneers of romantic poetry S. T. Coleridge (Biographia Literaria, 1817), who related Shakespeare's poem to the manifestation of the great instinct that had already worked on a hidden level and subsequently would lead the Bard to dramaturgy ${ }^{34}$.

James H. Lake obviously supports the points of view of Coleridge's followers and consistently asserts that there are two streams in the poem - the comic one, which colors the behavior of each of the characters in some episodes, and the tragic stream, which becomes dominant after Venus has learnt of Adonis's intentions of hunting the boar $^{35}$ The tragic element attains power and reaches its climax in the

${ }^{31}$ Ibid. C. 202.

${ }^{32}$ Ibid. C. 202.

33 Lake J. H. Shakespeare's Venus : An Experiment in Tragedy. Shakespeare Quartely. 1974. Vol. 25. № 3 (Summer). P. 352.

${ }^{34}$ Ibid.

35 Ibid. 
goddess's final address to the flower that has grown from the hunter's blood. The very presence of the tragic constituent makes the image of Venus rise in the recipients' estimation ${ }^{36}$.

In the essay The Shakespearean Venus and Adonis the Canadian Shakespearean scholar Nancy Lindheim proclaims this poem to be "a pivotal work in the author's technical as well as intellectual development" since it sheds new light on the issue of love and offers the original strategies of its literary representation basing on the use of the new techniques involving tonal shifts. The scholar thinks that "in Venus and Adonis ... we see the poet's very early attempts to manage considerable tonal complexity: he integrates comedy with tragedy, parody with straight representation, all the while manipulating our response to Venus so that by the time she comes to fear and then know Adonis's death, Shakespeare has moved us from ridicule to sympathy ${ }^{37}$ ",

On N. Lindheim's opinion "Venus is there to tell us that love is love even if it incorporates sexual desire, jealousy, anxiety, and other such negative feelings as the humiliation, cruelty and frustration of Marlowe's poem, or the powerlessness and self-abasement that Shakespeare will touch again in the sonnets ${ }^{38 \%}$. As for Adonis with his obsessive articulation of difference between love and lust, "the poem does not present him as the embodiment of any spiritual or intellectual position whatever. His governing principle instead is immaturity. He is simply too young to value another experience more highly than his games and his sleep $^{39}$,

The paper of the American scholar William R. Streitberger Ideal Conduct in "Venus and Adonis contains a number of original observations on the conflict in the poem. Examining Shakespeare's work in the broad literary context of that period, the scholar draws parallels between the ideas, put into the protagonists' words, and the ethical maxims that were popular in the time of Queen Elizabeth and espoused in most of authoritative sources, particularly, Thomas Elyot's treatise The Boke

\footnotetext{
${ }^{36}$ Ibid. P. 351-355.
}

37 Lindheim N. The Shakespearean Venus and Adonis. Shakespeare Quartely. 1986. Vol. 37. № 2 (Summer). P. 191.

\footnotetext{
${ }^{38}$ Ibid. P. 193-194.

${ }^{39}$ Ibid. P. 196.
} 
named the Governour (1531), providing a discussion of the basic principles of the notion of "virtue" 40 .

William R. Streitberger resting upon Elyot's book explains that Venus attempting to persuade Adonis to give up the hunt of the boar for the rabbit, in other words, to choose safe hunt instead of dangerous one, undermines his status of a nobleman. So, "Venus presents a moral threat to Adonis despite the fact that he is too young to love, that her attempt to persuade him from the noble to the easy hunt would destroy his virtues and make him an unfit gentleman, and that the striking similarities between Elyot's and Shakespeare's treatment of the material point to the fact that the seduction attempt is of real dramatic interest and is not merely example of Shakespeare playing with literary conventions ${ }^{41,}$.

Summarizing the research works that give an overall impression of the state of studies of Shakespeare's Venus and Adonis, it is worth declaring that the issues such as the genetic sources of the poem, its compositional structure, the peculiarities of the plot and the system of images have repeatedly been explored. As for those aspects of poetics that are correlated in a certain way with gender-oriented issues, they still need detailed analysis, the fruitful ground for which is laid in the writings of D. Bevington, W. R. Streitberger, M. Dobson, G. Kruzhkov, as well as in the works of culturologists who study the specificity of gender relations in the Middle Ages and the Renaissance.

\section{The Peculiarities of Shakespeare's interpretation of Ovid's version of the myth}

In Ovid's Metamorphoses, which served as a main source for the English author's poem, the priority is given to three key events: Venus falls in love with the young handsome Adonis; the hunter dies from a boar's attack; Venus turns the body of her beloved into a flower ${ }^{42}$. Keeping Ovid's plot outlines, Shakespeare creates effectively a new plot, the main features of which are the aesthetization of physical love and the poetization of an erotic component.

Due to Shakespeare's original interpretation, Ovid's plot turns into a kind of treasury of Renaissance ideas. This is evidenced by the

${ }^{40}$ Streitberger W. R. Ideal Conduct in "Venus and Adonis". Shakespeare Quartely 1975. Vol. 26. № 3 (Summer). P. 285-291.

${ }^{41}$ Ibid. P. 291.

42 Овидий. Метаморфозы / пер. с лат. С. В. Шервинского. Москва, 1977. C. $78-100$. 
rehabilitation of sensuality which was considered as a sin during the Middle Ages, by the voluminous description of erotic motives as well as by the panoramic image of the naked human body that became an object of apologetic interest and enthusiastic contemplation in the Renaissance.

Shakespeare's poem impresses, first, with the courage of the creative intentions of the author, who ventured into outright apologetics of physical love. The audiences, who had already been accustomed to the courtly stereotypes cultivated by the knightly novels, were shocked to some extent by the representation of the concept of corporality. At the same time, the form of this representation proved to be so virtuosic that the number of the poem's admirers far exceeded the number of its critics.

The body conceptions reflected in Venus and Adonis accumulate the experience of antiquity and the Middle Ages. This experience is renewed with the life-affirming pathos of anthropocentrism peculiar to the Renaissance.

The focus on the natural-bodily vision of the world, which is clearly evident in the poem, seems to bring the Renaissance text closer to its ancient sources. However, Shakespeare pays attention not only to the depiction of the human body, but also to the detailed descriptions of various bodily practices, making this epic work one of the best examples of the erotic poem of the Renaissance.

Adonis becomes the mouthpiece of ascetic views of the human body as a source of lust that destroys in the human soul the feeling of true love - the love to God. Trying to free himself from Venus's hugs and kisses the hunter constantly glooms ("Still is he sullen, still he lours and frets" ${ }^{43}$ ), sulks ("Pure shame and awed resistance made him fret" scolds her ("... now doth he frown, / And 'gins to chide" 45 ). His feelings and sexual desires are 'frozen' ("frosty in desire") even when he flushes with embarrassment ("red for shame"), pushing the goddess away. She, by any means, tries to melt his heart of flint:

'O, pity,' gan she cry, 'flint-hearted boy!

'Tis but a kiss I beg ; why art thou coy?'

${ }^{43}$ Shakespeare W. Venus and Adonis. Shakespeare's histories and poems. London; New York, 1953. V 2. P. 729.

${ }^{44}$ Ibid.

${ }^{45}$ Ibid. P. 728.

${ }^{46}$ Ibid. P. 729. 
After all, Venus realizes that the object of her love is even more solid than stone, as any naturally solid matter has the ability to soften under the influence of raindrops:

'Art thou obdurate, flinty, hard as steel?

Nay, more than flint, for stone at rain relenteth :

Art thou a woman's son, and canst not feel

What 'tis to love? how want of love tormenteth $?^{47}$

Venus and Adonis appear as the antipodes: if the young man personifies 'cold' ('frozen') beauty, the goddess embodies the beauty marked by the deep need for passionate love. She refers indeed to the Renaissance ideal of beauty rich in sensuality being the main attribute of corporality. Shakespeare anthropomorphizes Venus endowing her with boundless sensuality. Her every word is an incredibly shrill sound of passion. Embraced by an ardent, even mad love, the goddess resembles an eagle tearing ruthlessly her victim's feathers:

Even as an empty eagle, sharp by fast,

Tires with her beak on feathers, flesh and bone,

Shaking her wings, devouring all in haste,

Till either gorge be stuff'd or prey be gone $e^{48}$.

But Venus's love has not been cultivated only within passion and sexual affection. It is a powerful force that may lead to a harmonious whole formed by the combination of corporal and spiritual bonds, to give happiness, the impulse to a new life, and the feeling of full realization of vital strengths.

Nothing can stop Venus, neither Adonis's indifferent look, nor his rejection of her advances, because "she cannot choose but love; / And by her fair immortal hand she swears, / From his soft bosom never to remove" ${ }^{49}$. She wills to do anything for achieving her main purpose - to overcome the resistance of her proud beloved. She hereby is ready to enchant him with her sweet words, fly like a fairy and dance as a graceful nymph:

'Bid me discourse, I will enchant thine ear,

Or, like a fairy, trip upon the green,

Or, like a nymph, with long dishevell'd hair,

Dance on the sands, and yet no footing seen :

${ }^{47}$ Ibid. P. 732.
${ }^{48}$ Ibid. P. 728.
${ }^{49}$ Ibid. P. 729. 
Love is a spirit all compact of fire,

Not gross to sink, but light, and will aspire ${ }^{50}$.

It's interesting to note, that in Shakespeare's tragedy Romeo and Juliet we also find the comparison of strong love with the fiery substance which was considered, during the Renaissance, to be the lightest and highest of the four constituent elements of the world (earth, air, water and fire): "Love is a smoke made with the fume of sighs; / Being purged, a fire sparkling in lovers' eyes"

The ability of the goddess's body to carry out various transformations is a kind of allusion to a full development of the Renaissance personality and to the peculiarities of his/her corporality which, as the Russian philosopher Mikhail Bakhtin claims, "unites and accommodates all the diversity of the universe" ${ }^{, 52}$.

Since Adonis refuses natural corporal pleasures, the goddess cannot unlock the full potential of her corporality and fulfill her dream. She seems to lose her divine omnipotence and changes into an earthly sensual woman wooing endlessly and desperately her rebellious beloved, suffering and imploring him to accept her love. Excessive emotional stress provokes in her body the processes proper for any mortal person's organism such as lacrimation (... with her contending tears, / Which long have rain'd, making her cheers all wet ${ }^{53}$; And now she weeps .... ${ }^{54}$; With tears, which chorus-like her eyes did rain ${ }^{55}$ ) and sweating (... the love-sick queen began to sweat). Any nervous shock occasions the change in the color of her skin, and that is also natural for the human body (... her cheek was pale, and by and by / It flash'd forth fire ... ${ }^{56}$; The silly boy ... / Claps her pale cheek, till clapping makes it red ... ${ }^{57}$ ). The author of the poem, as we can see, blurs the boundaries between the goddess and the woman to a certain extent.

Thus, in Shakespeare's poem there is an obvious change in the semantics of the ancient (Ovid) plot, since the pivotal motive for the

${ }^{50}$ Ibid. P. 731.

${ }^{51}$ Shakespeare W. Romeo and Juliet. The complete works of Shakespeare / ed. by D. Bevington. New York, 1997. P. 983.

52 Бахтин М. М. Творчество Франсуа Рабле и народная культура Средневековья и Ренессанса. Москва, 1990. С. 404- 405.

${ }^{53}$ Shakespeare W. Venus and Adonis. P. 729.

${ }^{54}$ Ibid. P. 732.

${ }^{55}$ Ibid. P. 736.

${ }^{56}$ Ibid. P. 735.

${ }^{57}$ Ibid. P. 738. 
Renaissance poet is represented by Venus's desire to get any response to her feelings from the indifferent Adonis. In addition, the description of the heroine's natural sensual beauty can be regarded as a self-contained element of the poetics of Shakespeare's work, and this innovation completely corresponded to the requests of the Renaissance.

The whirlpool of passions and the real explosion of eroticism, which characterize Venus, destroy the ethical standards of sexual relations formed in the Middle Ages, and virtually affirm the new goodness of the Renaissance: hedonism, ability to enjoy life, the generous expression of emotions, freedom of actions, as well as the vigour of the mind and selfconfidence as key factors in achieving any purpose. The human being placed by the new age (the Renaissance) in the centre of the cosmic hierarchy has the right to a full-blooded sensual love offering terrestrial pleasures and providing future generations.

In the aesthetic space of the poem Venus and Adonis the sensual element gives rise to a high level of corporal communication. At the same time during this communication the body of the goddess acts as a living mechanism that affects Adonis. His movements are a peculiar reaction to Venus's actions, and his words reflect his inner psychological perception of the situation, in which he has found himself because of the goddess' desire for him:

And now Adonis, with a lazy spright,

And with a heavy, dark, disliking eye,

His louring brows o'erwhelming his fair sight,

Like misty vapours when they blot the sky,

Souring his cheeks, cries, 'Fie, no more of love!

The sun doth burn my face; I must remove ${ }^{58}$.

Tactile forms of expression play a very significant role in creating the communicative potential of the poem. Touch was, in the opinion of José Ortega y Gasset, "the original sense from which the others were gradually differentiated. From our more and more radical point of view it is clear that the decisive form of our intercourse with things is in fact touch"59. Therefore the Spanish philosopher claims that "touch and contact are necessarily the most conclusive factor in determining the

${ }^{58}$ Ibid. P. 731.

${ }^{59}$ Ortega y Gasset J. Man and People / transl. by W. R. Trask. New York, 1957. P. 72. 
structure of our world" ${ }^{\prime 60}$. Leonardo da Vinci expressing his opinion on the role of tactility in the process of acquiring the qualities of having experience wrote: "The more you speak by means of skin, clothing of feeling, the more you will acquire wisdom"61.

Venus's bodily actions towards Adonis are very important instruments of her sensuality and love language. She may surely get pleasure from his physical appearance and voice due to sight and hearing but these two senses won't be able to satisfy her main desire which consists of overcoming the corporal barrier between them. The goddess becomes obsessed with the idea of the direct communicative act, embedded in the very nature of tactility. For Venus, nothing can destroy this distance and bring her to the realization of her ultimate goal but the tactile actions:

Though neither eyes nor ears, to hear nor see,

Yet should I be in love by touching the $e^{62}$.

Even the plant organisms of nature kingdom surrounding the main characters of the poem, express the desire to speak in a tactile language:

And as she runs, the bushes in the way

Some catch her by the neck, some kiss her face,

Some twine about her thigh to make her stay,

She wildly breaketh from their strict embrace ${ }^{63}$.

The goddess thinks to make important steps on the path to the possession of Adonis's body by resorting to the kisses being a special form of corporality. Kissing the hunter, she tries to tell him 'without words' about the unwavering power of her feelings and the unbearable desire to penetrate the innermost depths of his corporal world.

So Venus is eager to kiss her beloved endlessly (Even so she kiss'd his brow, his cheek, his chin, I And where she ends she doth anew begin ${ }^{64}$ ), to lie eternally in order to get his kisses (He kisses her; and she, by her good will, / Will never rise, so he will kiss her still ${ }^{55}$ ) or give her heart for a thousand kisses (A thousand kisses buys my heart from me $e^{66}$ ).

\footnotetext{
${ }^{60} \mathrm{Ibid}$

${ }^{61}$ Calle-Gruber M. Jacques Derrida, la distance généreuse. Paris, 2009. P. 45.

${ }^{62}$ Shakespeare W. Venus and Adonis. P. 737.

${ }^{63}$ Ibid. P. 748.

${ }^{64}$ Ibid. P. 728.

${ }^{65}$ Ibid. P. 738.

${ }^{66}$ Ibid. P. 739.
} 
She is sure that the kiss is a nourishing source that can offer a fullfledged life to this "lifeless picture" or "well-painted idol", as the goddess metaphorically calls Adonis. Thus, the touches and kisses in Shakespeare's poem give sense to the entire bodily existence of the characters.

One could refer the sexual attraction of Shakespeare's heroine to ephebophilia (the sexual attraction an adult feels toward a mid-to-late adolescent) that was one of socially acknowledged cultural practices in the ancient world. The topic of sexual preferences for adolescents gained great popularity in ancient Greek literature, as witnessed, for example, by the Dialogues of Plato (The Banquet and The Rivals) and Xenophon (Banquet), the collection of Straton's epigrams etc.

Taking therefore into consideration the nature and intensity of penetration of such socio-cultural phenomena of antiquity into the bosom of the Renaissance culture, it will be mistaken to regard Venus's sexual behavior as a sexual deviation.

It is noticeable that Shakespeare's art of representation of corporality and bodily practices raises the whole poem almost to the level of the theatrical performance, the action of which is unfolding right before our eyes. This effect is created by the device of the sequence of bodily poses: 'she seizeth on his sweating palm'; 'she push'd him'; 'she stroke his cheek'; 'Sometimes she shakes her head, and then his hand, / Now gazeth she on him, now on the ground; / Sometimes her arms infold him like a band ...'; 'With one fair hand she heaveth up his hat, / Her other tender hand his fair cheek feels...'; 'He wrings her nose, he strikes her on the cheeks, / He bends her fingers, holds her pulses hard, / He chafes her lips...'; 'Her arms do lend his neck a sweet embrace; Incorporate then they seem; face grows to face'; 'Their lips together glued, fall to the earth ${ }^{, 67}$.

The change of various poses seems "enliven" the poem's artistic space, transforming its text into an inexhaustible source of readers' imagination. The kaleidoscopic images of body movements do not interfere with the logical structure and cause-and-effect relationship between scenes of the poem. On the contrary, it seems that not a sequence of events contributes to the mobility of the bodies, but a number of different corporal manifestations.

${ }^{67}$ Ibid. P. $727-755$. 
Thus, corporality provides a major impetus for the plot of Shakespeare's Venus and Adonis, and the 'parade' of bodily movements can be considered as a communicative structure that is more expressive than mere verbalization of the series of events, collisions, etc. The desire to attain specific aims (to excite, enchant, provoke bodily sensations, give pleasure, etc.) encourages the author to activate the reader's memory and recall bygone feelings (including tactile ones) and emotions.

\section{CONCLUSIONS}

The poem Venus and Adonis by William Shakespeare was enormously successful during his life time. It was reprinted more frequently than any other of his works, with ten editions issued between 1593 and 1613. Due to it Shakespeare was known above all as "a sweet master", "the Ovid of England", a "witty" "mellifluous" and "honeytongued" man of letters.

Shakespeare's Venus and Adonis was much admired by his contemporary readers and fellow writers. For example, Francis Meres, Gabriel Harvey, Richard Barnfield and John Weever praised this poem in a panegyric style.

However the literary evaluations of Venus and Adonis weren't unanimous. Some Shakespeare's contemporaries as Thomas Freeman and John Davies found the poem to be the promoter of lust.

Most of Shakespeare's contemporaries, while alluding to Venus and Adonis, paid attention not so much to the plot of the poem that was well known in Elizabethan England, but rather to the peculiarities of the Bard's interpretation of the ancient myth and the poetic innovations of his own.

The $20-21^{\text {st }}$ centuries research works, making survey of Shakespeare's Venus and Adonis, can be broadly classified into two main categories: representative-review papers and proper analytical ones.

The first group of works mostly includes the prefaces to numerous editions of the poem, the references of Shakespeare's contemporaries, brief companions to the genesis of the mythological plots inspiring the English poet, as well as the descriptions of the plot lines of Shakespeare's poem, accompanied by critical comments. The authors of such papers as, in particular, V. Botkin, M. Morozov, A. Anikst, V. Komarova, O. Alekseenko, D. Bevington, M. Dobson and others, "fit" Shakespeare's text into the general literary panorama of his age and highlight the character of inter-communication between traditions and innovations. 
The second category of research works consists of the articles examining specific issues of the poetics paradigm of Shakespeare's Venus and Adonis, the texts considered as original sources for Shakespeare's poem, and the analytical observations interwoven into a large research context. Among the scholars aimed at these issues are T. W. Baldwin, G. Bullough, I. Shvedov, G. Kruzhkov, J. H. Lake, C. S. Lewis, R. Putney, B. E. Cantelupe, M. C. Bradbrook, H. T. Price, R. P. Miller, A. Ch. Hamilton, J. W. Lever, K. A. Muir, N. Rabkin, N. Lindheim, W. R. Streitberger, and others.

In spite of the fact Shakespeare's poem is inspired by and largely based on stories found in Ovid's narrative poem The Metamorphoses, it differs greatly from the Roman poet's version and can be considered innovative. These innovations have been mostly connected with the shift of semantic accents from the event to the form of event representation. In other words, Shakespeare has transformed the famous ancient myth about Venus's love to the young hunter Adonis into a virtuoso artistic interpretation of sensual love, depicted through the prism of corporality.

Thus, corporality, I regard as a key ideological and artistic concept of Shakespeare's poem, completely renews the classic version of the myth. So, the plot borrowed from Ovid's Metamorphosis becomes imbued with juicy and lively representations of corporality.

Manifesting the rights of natural sensual beauty, the poetization of which is one of the main factors forming the plot, Shakespeare, in effect, makes a kind of ethical and aesthetic breakthrough. He convincingly demonstrates to both readers and his fellow writers that the erotic and corporeal components, which have long been tabooed by public morality and not allowed on the pages of literary works, may serve as a source of creative inspiration and generate poetic imagery elevating them to the level of sublime poetry.

\section{SUMMARY}

The author of this paper makes a survey of the critical reception of Shakespeare's Venus and Adonis, illustrating the literary comments of the Bard's contemporaries as well as exploring the modern critical discourse aimed to the poem. The peculiarities of the reception of the antique plot about the love of the goddess Venus for the young hunter Adonis in the poem by W. Shakespeare are also under consideration in the article. In the scholar's opinion, the English Renaissance poet together with preserving the frame of the antique myth creates a new plot at the same time. 
Aestheticization of corporal love and poetization of bodily practices clearly come out in Shakespeare's poem.

Keywords: critical reception, erotic poem, sensuality, corporality, bodily practices.

\section{REFERENCES}

1. Алексєєнко О. Венера i Адоніс / пер. 3 англ. О. Мокровольського. Шекспір В. Твори : в 6 m. Київ, 1986. Т. 6. C. 769-771.

2. Аникст А. А. Поэмы, сонеты и стихотворения Шекспира. У. Шекспир. Полное собрание сочинение: в $8 \mathrm{~m}$. / под ред. А. Смирнова, А. Аникста. Москва, 1960. Т. 8. С. 570.

3. Бахтин М. М. Творчество Франсуа Рабле и народная культура Средневековья и Ренессанса. Москва, 1990. 543 с.

4. Боткин В. П. Литература и театр в Англии до Шекспира. Полное собрание сочинений В. Шекспира в переводе русских писателей : в $3 \mathrm{~m}$. / под ред. Д. Михаловского. Санкт Петербург, 1899. T. 3. C. 5-41. URL: http://az.lib.ru/b/botkin_w_p/text_ 0110oldorfo.shtml.

5. Комарова В. П. Чувственность и разум в поэмах "Венера и Адонис" и "Обесчещенная Лукреция". Метафоры и аллегории 6 произведениях Шекспира. Ленинград, 1989. С. 23-27.

6. Кружков Г. М. Лекарство от Фортуны. Поэты при дворе Генриха VIII, Елизаветы Английской и короля Иакова. Москва, 2002. $528 \mathrm{c}$.

7. Морозов М. М. Встреча с графом Саутгэмптоном. “Венера и Адонис". “Лукреция”. Шекспир. Москва, 1956. С. 16-27.

8. Овидий. Метаморфозы / пер. с лат. С. В. Шервинского. Москва, 1977. С. 78-100.

9. Шведов Ю. Ф. Творчество Шекспира. Вильям Шекспир. Исследования. Москва, 1977. С. 267-347.

10. A Companion to Shakespeare Studies / ed. by H. GranvilleBarker, G. B. Harrison. New York, 1960. 390 p.

11. Baldwin Th. W. On the Literary Genetics of Shakespeare's Poems and Sonnets. Urbana, 1950. 404 p.

12. Bevington D. Venus and Adonis. The Complete works of Shakespeare / ed. by D. Bevington. New York, 1997. P. 1608-1609.

13. Bullough G. Narrative and Dramatic Sources of Shakespeare. London, 1975. 423 p. 
14. Calle-Gruber M. Jacques Derrida, la distance généreuse. Paris, 2009. $188 \mathrm{p}$.

15. Dobson M. Venus and Adonis. The Oxford Companion to Shakespeare / ed. by M. Dobson, S. Wells. Oxford, 2008. P. 510-512.

16. Gililov I. The Shakespeare Game, Or, The Mystery of the Great Phoenix. New York, 2003. 482 p.

17. Greenblatt S. Will in the World. How Shakespeare became Shakespeare. London, 2004. 430 p.

18. Lake J. H. Shakespeare's Venus : An Experiment in Tragedy. Shakespeare Quartely. 1974. Vol. 25. № 3 (Summer). P. 351-355.

19. Lindheim N. The Shakespearean Venus and Adonis. Shakespeare Quartely. 1986. Vol. 37. № 2 (Summer). P. 190-203.

20. Ortega y Gasset J. Man and People / transl. by W. R. Trask. New York, 1957. 272 p.

21. Shakespeare $\mathrm{W}$. Romeo and Juliet. The complete works of Shakespeare / ed. by D. Bevington. New York, 1997. P. 980-1020.

22. Shakespeare W. Venus and Adonis. Shakespeare's histories and poems. London; New York, 1953. V 2. P. 727-755.

23. Srinivasa Iyengar K. R. Shakespeare : His World and His Art. Delhi, 1984. $711 \mathrm{p}$.

24. Streitberger W. R. Ideal Conduct in "Venus and Adonis". Shakespeare Quartely 1975. Vol. 26. № 3 (Summer). P. 285-291.

25. The New Oxford Shakespeare: The Complete Works / ed. by G. Taylor, J. Jowett, T. Bourus, G. Egan. Oxford, 2016. 3392 p.

26. Wells S. Shakespeare. A life in Drama. New York - London, 1997. $411 \mathrm{p}$.

27. Wells S. Shakespeare For All Time. London, 2002. 442 p.

Information about the author: Blondel (Khrabrova) Hanna Mykolaivna Candidate of Philology (PhD), Docent (Assistant Professor) 